\title{
SISTEM INFORMASI BURSA KERJA KHUSUS DENGAN REKOMENDASI MENGGUNAKAN METODE CONTENT BASED FILTERING DI STMIK YADIKA BANGIL
}

\author{
M. Noval Riswandha, ${ }^{1)}$ Miftakhul Nuryuda ${ }^{2)}$, \\ Teknik Informatika, STMIK Yadika Bangil, \\ Jl. Bader No.9, Kalirejo, Bangil, Pasuruan, Jawa Timur 67153 \\ email: mriswandha@stmik-yadika.ac.id, mnyuda23@mhs.stmik-yadika.ac.id
}

\begin{abstract}
The author makes a special job stock information system (BKK) in STMIK YADIKA Bangil because the job search process for alumni students is currently running less effectively, alumni students should seek information to BKK officers, while BKK officers have to look for alumni data who have not got a job. Therefore, the authors make a special job market information system with recommendations using content based filtering method. Content based filtering method can be used to suggest job vacancy information in accordance with user profile or job seeker so as to facilitate the information search process. System of recommendation in the application of special job market is used to recommend the right job vacancy information for the alumni of the student.In this system expected alumni students Can receive job vacancy information properly and in accordance with the criteria it has
\end{abstract}

Keywords: special job fair (BKK), Content Based Filtering, Recommendation System.

\section{PENDAHULUAN}

Setelah menempuh sekolah pendidikan tinggi masih ada beberapa alumni mahasiswa yang belum mendapatkan pekerjaan di karenakan informasi yang didapatkan sedikit. Sehingga sekolah perguruan tinggi STMIK Yadika Bangil membantu mahasiswa untuk mendapatkan informasi pekerjaan. Salah satu cara perguruan tinggi ini dalam memberikan informasi tentang lowongan pekerjaan adalah mencari data alumni yang belum bekerja dan selanjutnya akan ditindak lanjuti dengan di sms oleh petugas BKK. Namuncara tersebut tidak dapat di terima dengan jelas oleh para alumni. Dengan demikian, cara bursa kerja seperti itu masih belum cukup efektif dan efisien. website sebagai portal informasi lowongan pekerjaan yang dapat dijadikan sarana penyebaran dan pengaksesan informasi yaitu website dengan system rekomendasi. Metode yang diusulkan dalam system rekomendasi adalah content based filtering. Metode content based filtering dapat digunakan untuk menyarankan informasi lowongan kerja yang sesuai dengan profil pengguna atau pencari kerja sehingga mempermudah proses pencarian informasi. Sistem rekomendasi dalam aplikasi bursa kerja khusus digunakan untuk merekomendasikan informasi lowongan pekerjaan yang tepat bagi alumni mahasiswa STMIK Yadika Bangil yang membutuhkan informasi pekerjaan. Kriteria dalam lowongan kerja yang dipublikasikan oleh perusahaan biasanya berdasarkan jenis kelamin, umur, pendidikan terakhir, nilai IPK pengalaman kerja dan keahlian yang dimiliki pelamar semua aspek tersebut sangat lah penting dalam proses perekrutan tenaga kerja oleh perusahaan. Adapun tujuan penelitian ini, adalah:

1) Untuk membantu mahasiswa dalam mencari lowongan pekerjaan yang di inginkan melalui metode content based filtering dengan rekomendasi
2) Untuk mengimplementasikan metode content based filtering dalam sistem pencarian lowongan pekerjaan

\section{METODE PENELITIAN}

1. Fokus dan Tempat Penelitian

Pada penelitian ini penulis memfokuskan pada proses pengelolaan data mahasiswa alumni STMIK YADIKA Bangil yang belum mendapatkan lowongan pekerjaan.

Lokasi yang dipilih dalam penelitian adalah STMIK Yadika Bangil yang berlokasi di jalan Bader No 9 Kalirejo, Bangil Pasuruan.

2. Alat Penelitian

a. Perangkat Lunak (Software)

b. Perangkat Keras (Hardware)

3. Metode Pengumpulan Data

Penelitian kualitatif digunakan jika masalah belum jelas, untuk mengetahui makna yang tersembunyi, untuk mengembangkan teori serta memastikan kebenaran data. Beberapa metode pengumpulan data yang dilakukan penulis, yaitu:

a. Observasi

b. Wawancara

c. Studi Pustaka

d. Internet Browsing

e. Perancangan sistem

f. Pembuatan program

g. Uji coba sistem

h. Analisa Hasil program

4. Metode Analis

1. Tahap Analisis sistem

Pada tahap initerdapat langkah-langkah antara lain:

a. Mengidentifikasi masalah pengelolahan bkk di STMIK YADIKA

b. Memahami kerja dari sistem yang ada di STMIK YADIKA

c. Menganalisis system informasi

d. Membuat laporan hasil analisis

2. Tahap desain system 
Hasil dari tahap analisis sistem yang telah dilakukan akan dipergunakan peneliti dalam melakukan desain sistem. Desain sistem yang dilakukan meliputi penelitian:

a. Desain model

Dalam tahap ini, peneliti akan membuat desain-desain model dari sistem rekomendasi bursa kerja khusus yang akan di usulkan. Dalam desain model ini ada 3 bentuk model yang akan digunakan untuk menjelaskan bagaimana nantinya fungsifungsi di sistem rekomendasi secara logical bekerja. Desain model diGambarkan dengan Usecase Diagram, Activity Diagram, Sequence Diagram.

b. Desain database

Dalam tahap ini peneliti akan merancang database sesuai dengan kebutuhan dari desain memodel untuk aplikasi sistem rekomendasi bursa kerja khusus.

c. Desain Interface

Desain interface dari sistem rekomendasi bursa kerja khusus ini terdiri dari 2 page berikut:

1. Login page

Pada halaman ini user diharuskan memasukkan member ID dan password untuk bisa mengakses sistem.

2. Main page

Pada main page ini terdapat 2 macam tampilan menu yang secara otomatis ditampilkan oleh sistem berdasarkan history lowongan kerja.

\section{Analisis dan Perancangan Sistem}

Analisis Kebutuhan Sistem

Perangkat keras yang digunakan dalam perancangan sistem ini adalah:
a. Unit laptop 10",
b. Harddisk $320 \mathrm{~GB}$
c. Memory $1 \mathrm{~GB}$
2. Perangkat Lunak (software)

Perangkat lunak adalah satu program atau utilitas yang digunakan untuk menjalankan perangkat keras komputer. Perangkat lunak yang digunakan dalam perancangan sistem ini adalah:
a. Sistem Operasi : Windows 7
b. Browser : Google Chrome
c. Bahasa Pemrograman : PHP, CSS
d. Manajemen Database : MySQL
e. Editor PHP : Notepad++
f. Aplikasi Server : XAMPP
g. Desain Diagram : MS ,Visio 2007, Power
Designer 16.5

Perancangan Sistem

Dalam Gambar 1 adalah use case diagram memperlihatkan hubungan antara actor dan use case. Actor merepresentasikan seorang user yang berinteraksi dengan sistem. Fungsionalitas sistem didefinisikan kedalam use case dari sudut eksternal yang berguna untuk uji kelayakan sistem. Setiap usecase akan disertai penjelasan yang diuraikan dalam usecase scenario, yang menguraikan nama usecase, usecase yang terkait, aksi actor dalam Sistem Informasi Bursa Kerja Khusus.

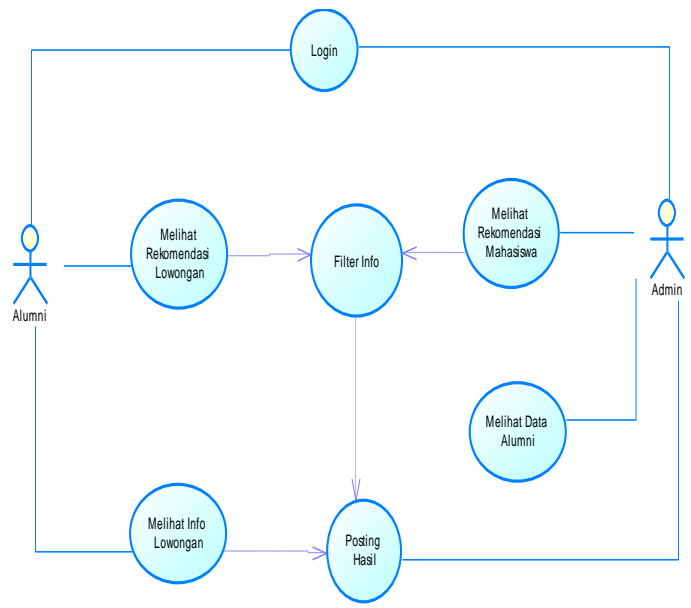

Gambar 1. Use Case Diagram sistem

Keterangan:

Di dalam sistem (aplikasi) yang dijalankan oleh actor (user) terdapat Menu seperti yang terdapat pada Gambar 5.3.1 yaitu menu Info Lowongan dan Rekomendasi Lowongan

- $\quad$ Di dalam sistem (aplikasi) yang dijalankan oleh actor (admin) terdapat Menu seperti yang terdapat pada Gambar 5.3.1 yaitu menu Data Alumni dan Rekomendasi Mahasiswa

Perancangan Aktivity Diagram

Gambar 2 dan Gambar 3 MengGambarkan berbagai alir aktivitas dalam sistem yang sedang dirancang, bagaimana masing-masing alir berawal, decision yang mungkin terjadi dan bagaimana mereka berakhir.

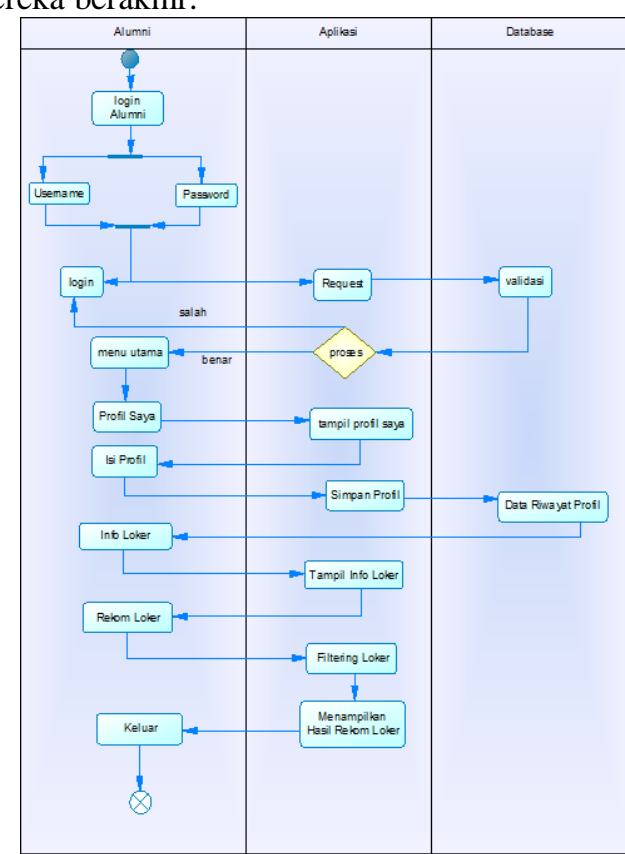

Gambar 2. Aktivity Diagram user alumni

Keterangan:

- Pengguna memulai aplikasi dan memilih menu login alumni, kemudian memasukkan username, password dan klik login 
- Setelah dklik login, selanjutnya akan di request dan divalidasi kemudian diproses, ketika memasukkan username salah maka akan kembali lagi ke menu login, apabila memasukkan dengan benar maka akan tampil dimenu utama

- Setelah masuk pada tampilan Menu utama, klik menu profil saya kemudian isi profil tersebut sesuai dengan identitas selanjutnya simpan profil.

- Kemudian klik info loker selanjutnya akan muncul tampilan info loker setelah itu pengguna merekomendasi info lowongan yang sesuai dengan profil pengguna dan sistem akan secara otomatis memfilter lowongan kerja yang sesuai dengan data pengguna

- Kemudian akan muncul hasil dari rekomendasi lowongan kerja tersebut.

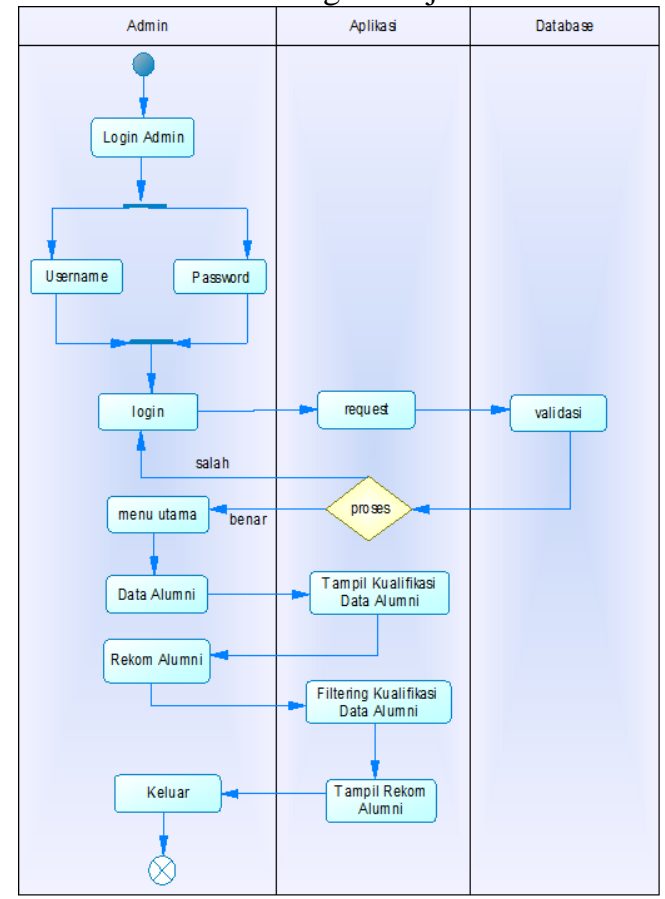

Gambar 3. Aktivity Diagram user admin

\section{Keterangan:}

- Pengguna memulai aplikasi dan memilih menu login admin, kemudian memasukkan username, password dan klik login

- Setelah dklik login, selanjutnya akan di request dan divalidasi kemudian diproses, ketika memasukkan username salah maka akan kembali lagi ke menu login, apabila memasukkan dengan benar maka akan tampil dimenu utama

- Setelah masuk pada tampilan Menu utama, klik menu data alumni kemudian akan tampil kualifikasi data alumni

- Kemudian admin akan merekom alumni sesuai dengan kualifikasi data dari perusahaan selanjutnya sistem akan memfilter kualifikasi data alumni Kemudian akan tampil hasil dari rekomendasi alumni tersebut.

Gambar 4 dan Gambar 5 Sequence Diagram yang mengGambarkan interaksi antar objek dan mengidentifikasi komuniasi antara objek-objek tersebut. Diagram ini juga menunjukkan serangkaian pesan yang dipertukarkan oleh objekobjek yang melakukan suatu tugas atau aksi tertentu.

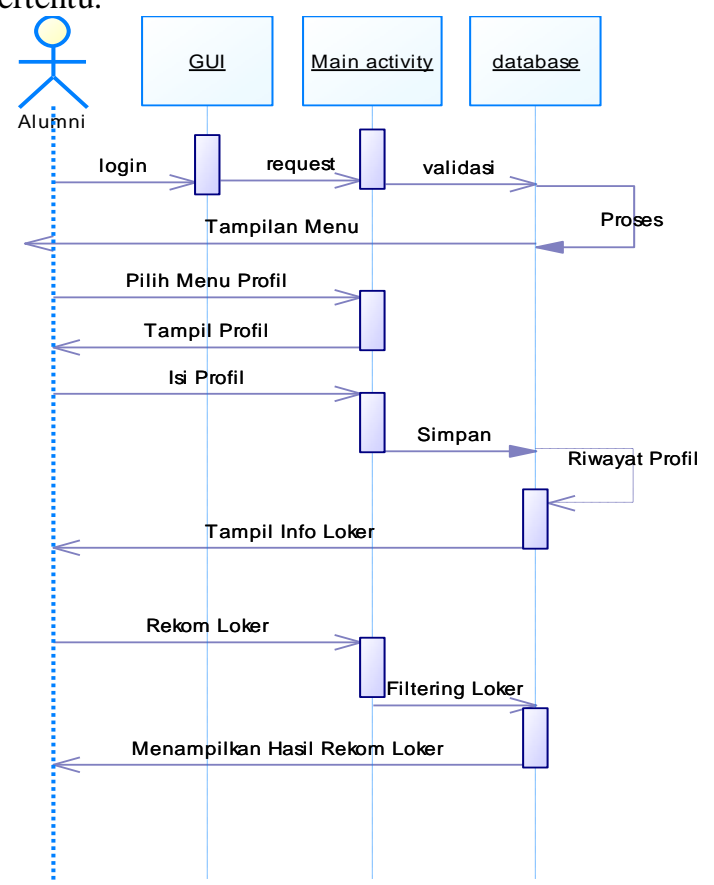

Gambar 4. Sequence Diagram user Alumni

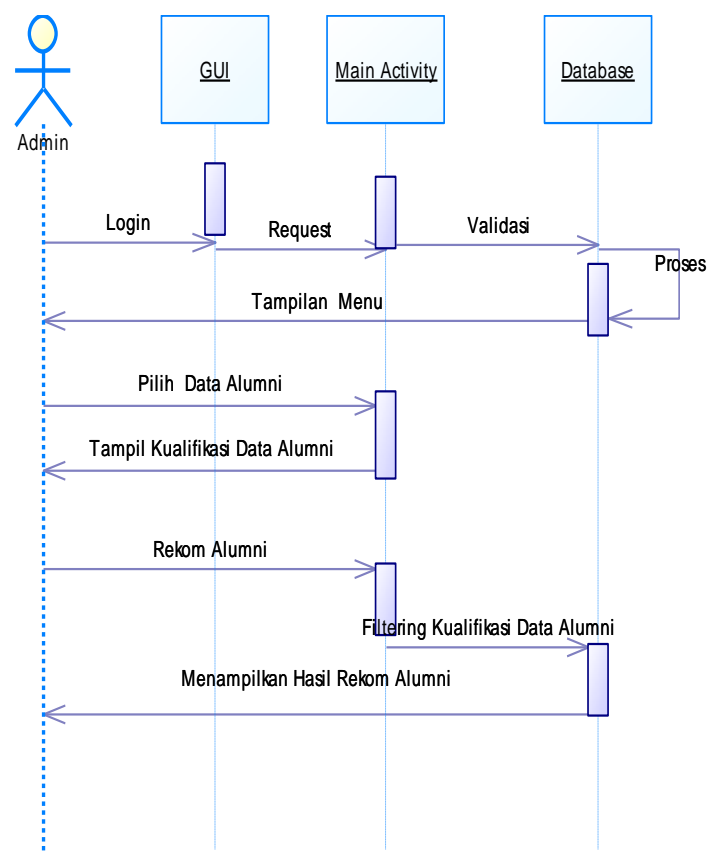

Gambar 5. Sequence Diagram user Admin

\section{HASIL DAN PEMBAHASAN}

Sistem rekomendasi ini dibuat oleh penulis menggunakan bahasa pemrograman PHP dan Database MySQL. Penulis menggunakan bahasa ini karena mudah dipahami dalam pembuatan sistem dan juga dapat digabungkan dengan bahasa pemrograman CSS yang mendukung penggunaan program ini. Sistem informasi ini dijalankan menggunakan internet dengan menggunakan website sistem bursa kerja khusus. Website ini hanya digunakan untuk mahasiswa dan alumni STMIK Yadika Bangil. Untuk login ke website 
tersebut mahasiswa harus menggunakan username dan password yang telah dimiliki oleh mahasiswa.

Sistem rekomendasi bursa kerja khusus yang menggunakan metode content based filtering merupakan website yang digunakan untuk menyarankan informasi lowongan kerja yang sesuai dengan profil pengguna atau pencari kerja sehingga mempermudah proses pencarian informasi. Dalam implementasinya sistem rekomendasi dalam aplikasi bursa kerja khusus bertujuan untuk merekomendasikan informasi lowongan pekerjaan yang tepat bagi alumni mahasiswa STMIK Yadika Bangil yang membutuhkan informasi pekerjaan.

Halaman login adalah halaman yang berfungsi untuk login mahasiswa dan admin dengan memasukkan username dan password untuk dapat masuk kedalam sistem. Pada sistem bursa kerja khusus ini terdapat dua login yaitu login admin dan login mahasiswa.

Yang menjadi admin adalah petugas dari BKK, dan untuk login ke adminpetugas harus mengisi username dan password terlebih dahulu selanjutnya klik login, maka akan tampil Gambar seperti Gambar 6 di bawah ini.

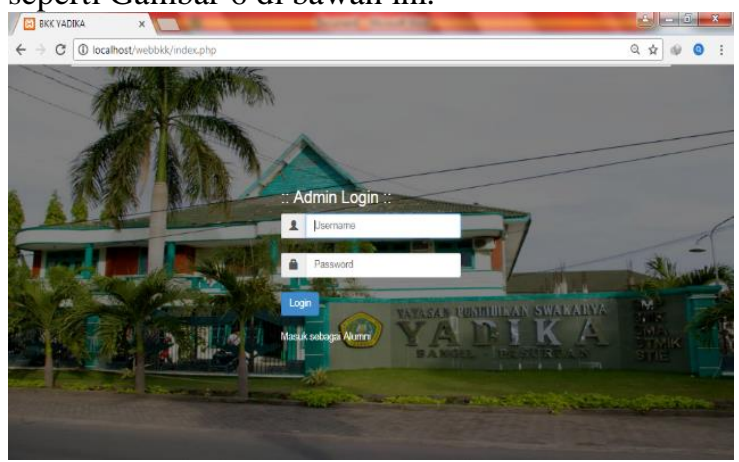

Gambar 6. halaman login admin

Pada Gambar 7 di halaman utama terdapat menu data alumni, data perusahaan, data lowongan, rekomendasi mahasiswa dan, logout.

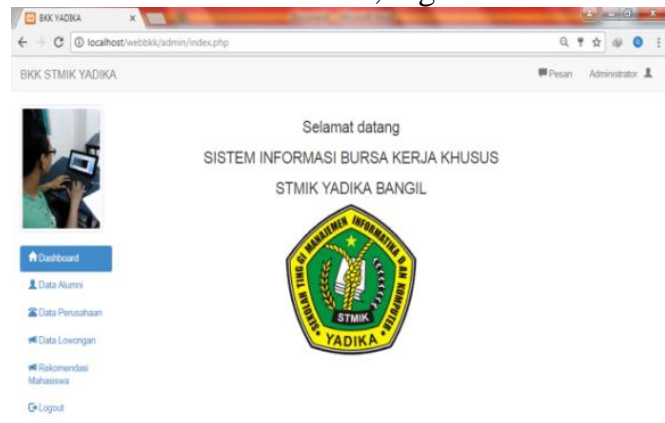

Gambar 7. halaman utama admin

Pada Gambar 8 di halaman data alumni ini berisi tentang data dari alumni mahasiswa. Didalam menu data alumni terdapat menu input, menu detail dan menu hapus.

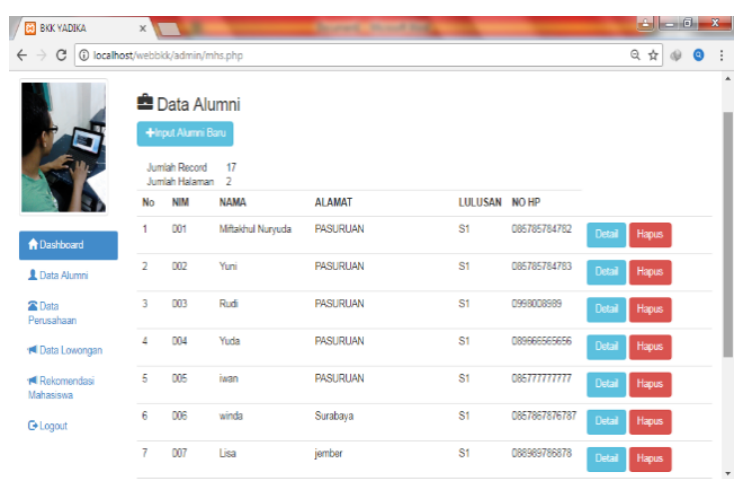

Gambar 8. halaman data alumni

Pada menu input alumni berfungsi untuk memasukkan data alumni yang baru, didalam tampilan menu input alumni baru terdapat kolom Nim, username, dan password seperti Gambar 9.

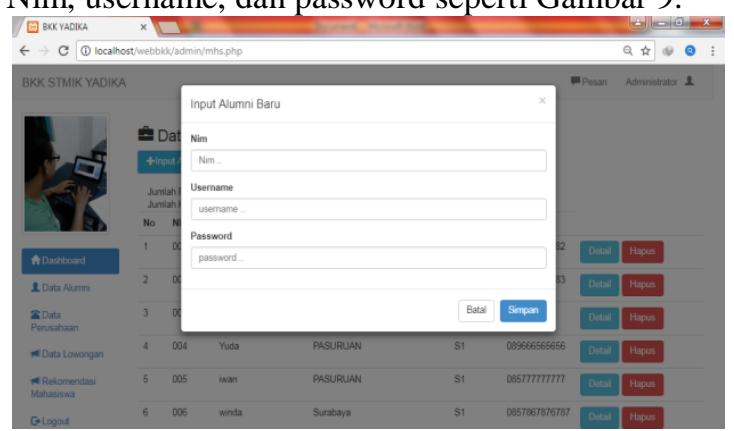

Gambar 9. menu input alumni baru

Pada Gambar 10 di menu data perusahaan terdapat tampilan menu input perusahaan, detail, edit, dan hapus.

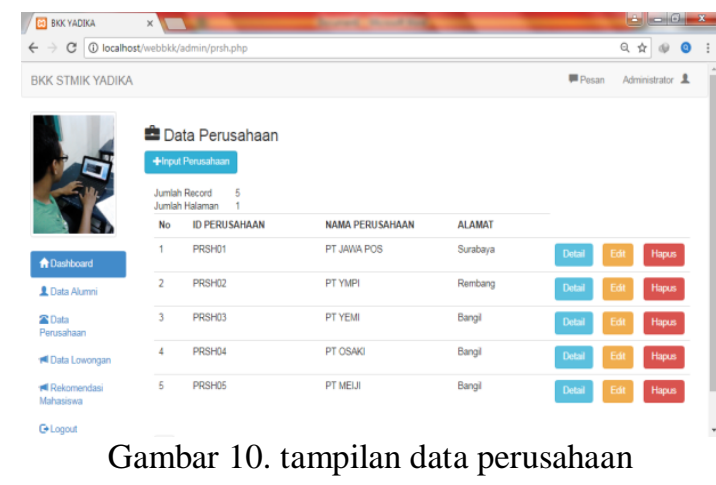

Pada Gambar 11 di menu data lowongan terdapat tampilan menu input lowongan, detail, edit, dan hapus

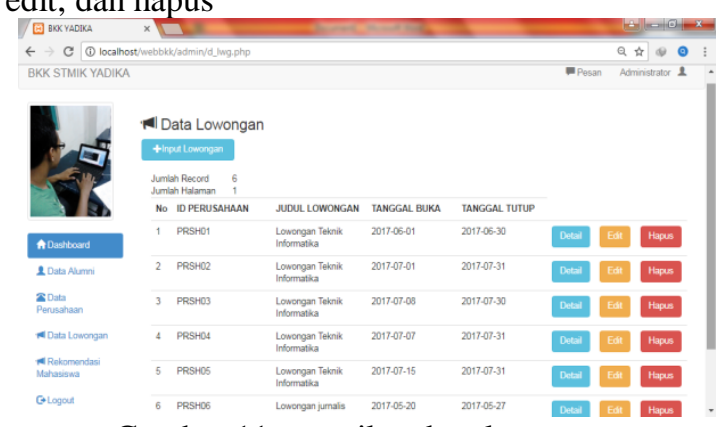

Gambar 11. tampilan data lowongan 
Pada tampilan menu rekomendasi mahasiswa di Gambar 12 berfungsi untuk merekomendasi mahasiswa yang sesuai dengan kriteria peryaratan lowongan pekerjaan yang dibutuhkan oleh perusahaan.

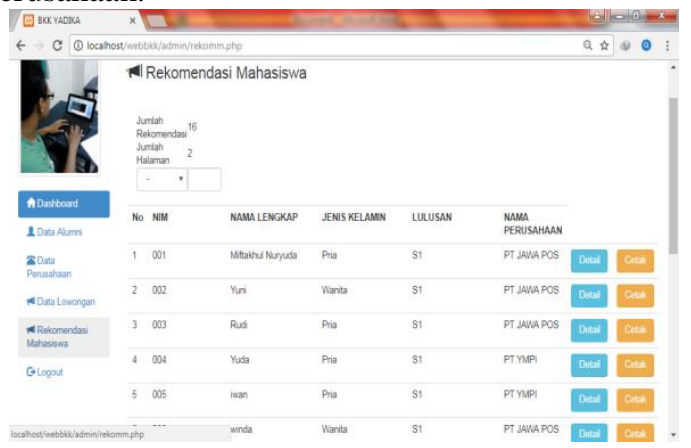

Gambar 12. tampilan rekomendasi mahasiswa

Data yang sudah direkomendasi dapat dicetak, apabila ingin mencetak data tersebut maka klik menu cetak pada tampilan rekomendasi mahasiswa sehingga muncul tampilan seperti Gambar 13 di bawah ini.

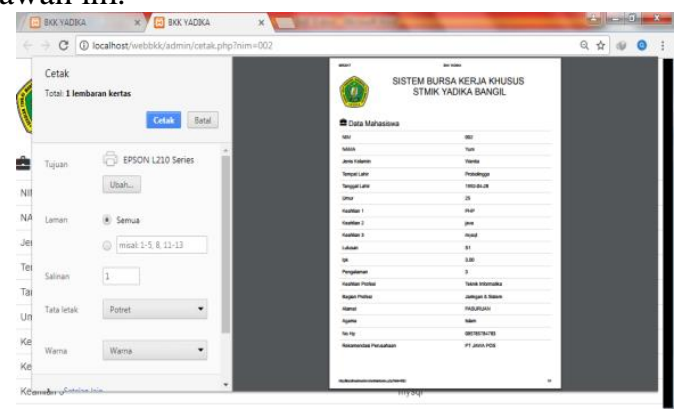

Gambar 13. tampilan menu cetak

Pada tampilan login alumni mahasiswa di Gambar 14 harus mengisi user login yang terdiri dari username dan password kemudian klik login.

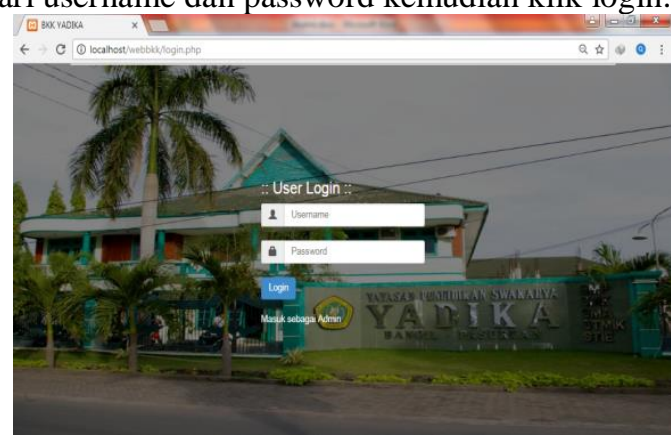

Gambar 14. tampilan login alumni

Pada halaman utama di Gambar 15 terdapat menu profil saya, rekomendasi lowongan, info lowongan dan, logout.

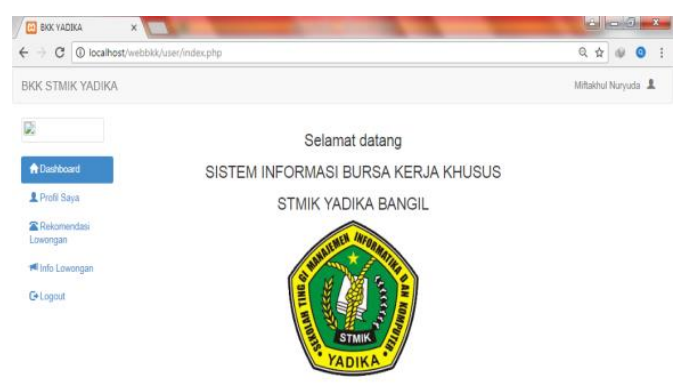

Gambar 15. tampilan menu dashboard

Pada menu profil ini mahasiswa harus mengisi data identitas yang sesuai dengan keahlian masingmasing seperti Gambar 16 di bawah ini.

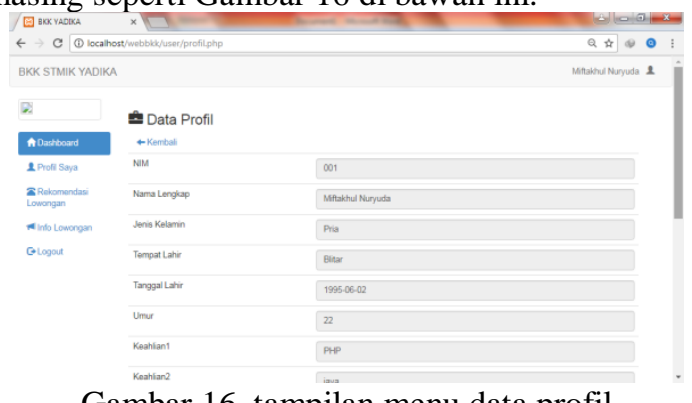

Gambar 16. tampilan menu data profil

Pada menu info lowongan alumni di Gambar 17 dapat melihat lowongan pekerjaan di website bursa kerja. Didalam menu info lowongan terdapat menu detail.

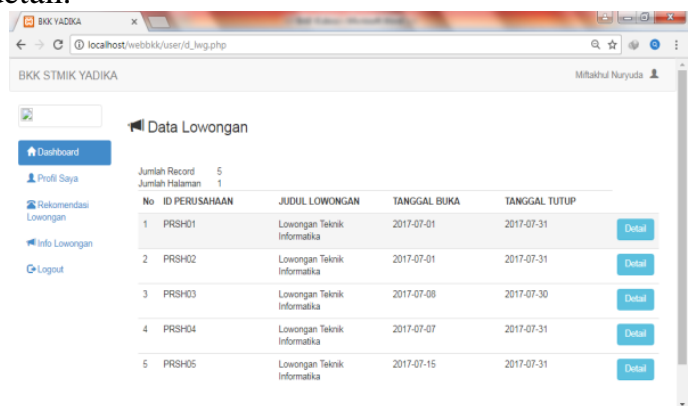

Gambar 17. menu info lowongan

Pada tampilan rekomendasi lowongan di Gambar 18 berfungsi untuk merekomendasi mahasiswa yang sesuai dengan kriteria peryaratan lowongan pekerjaan yang di butuhkan oleh perusahaan. Pada tampilan rekomendasi lowongan terdapat menu detail

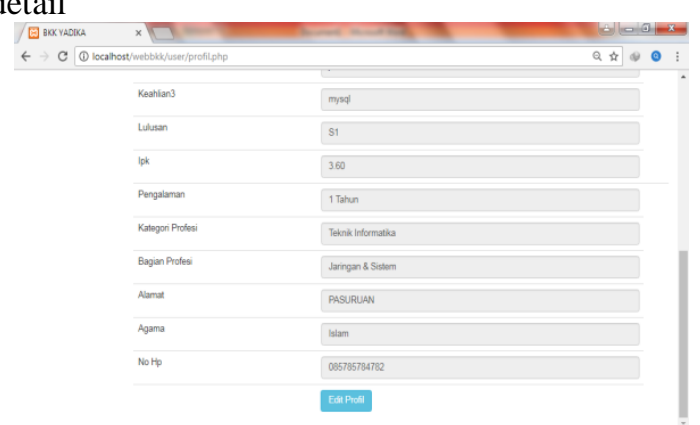

Gambar 18. tampilan menu rekomendasi lowongan

Pengujian atau evaluasi aplikasi bertujuan untuk memastikan bahwa aplikasi telah memiliki 
fungsi seperti yang diharapkan dan mencari kesalahan yang terdapat pada aplikasi website bursa kerja di STMIK Yadika Bangil dengan rekomendasi menggunakan metode content based filtering. Pengujian ini dilakukan untuk menguji bahwa implementasi program telah sesuai dengan target.

Metode pengujian yang digunakan adalah pengujian blackbox. pengujian blackbox dimana pengujian ini dilakukan untuk memastikan tanggapan/respons atas suatu event atau masukan akan menjelaskan proses yang tepat dan menghasilkan keluaran/output sesuai dengan rancangan yang telah dibuat. Uji ini dilakukan dengan dua login yaitu login admin dan login alumni dengan hasil secara berturut-turut dalam Tabel 1 dan Tabel 2:

Tabel 1. Tabel Pengujian website admin

\begin{tabular}{|c|c|c|c|}
\hline No & Input/ Event & Output & Hasil \\
\hline 1. & $\begin{array}{l}\text { Klik tombol } \\
\text { login admin } \\
\text { (masukkan } \\
\text { data username } \\
\text { dan password } \\
\text { valid) }\end{array}$ & $\begin{array}{l}\text { Menampilkan } \\
\text { Login Sukses } \\
\text { dan } \\
\text { menampilkan } \\
\text { Form } \quad \text { Menu } \\
\text { Utama }\end{array}$ & $\begin{array}{l}\text { Sesuai } \\
\text { / OK }\end{array}$ \\
\hline 2. & $\begin{array}{l}\text { Klik menu } \\
\text { data alumni }\end{array}$ & $\begin{array}{l}\text { Menampilkan } \\
\text { semua data } \\
\text { alumni }\end{array}$ & $\begin{array}{l}\text { Sesuai } \\
\text { / OK }\end{array}$ \\
\hline 3 & $\begin{array}{l}\text { Klik menu } \\
\text { rekomendasi } \\
\text { mahasiswa }\end{array}$ & $\begin{array}{l}\text { Menampilkan } \\
\text { hasil } \\
\text { rekomendasi } \\
\text { alumni yang } \\
\text { sesuai dengan } \\
\text { persyaratan dari } \\
\text { perusahaan }\end{array}$ & $\begin{array}{l}\text { Sesuai } \\
\text { / OK }\end{array}$ \\
\hline 4 & $\begin{array}{l}\text { Klik menu } \\
\text { logout }\end{array}$ & $\begin{array}{l}\text { Mengakhiri } \\
\text { program }\end{array}$ & $\begin{array}{l}\text { Sesuai } \\
\text { / OK }\end{array}$ \\
\hline
\end{tabular}

1.2.1 login alumni

Tabel 2. Tabel Pengujian website alumni

\begin{tabular}{|c|c|c|c|}
\hline No & Input/Event & Output & Hasil \\
\hline 1. & $\begin{array}{l}\text { Klik tombol } \\
\text { login alumni } \\
\text { (masukkan } \\
\text { data } \\
\text { username } \\
\text { dan } \\
\text { password } \\
\text { valid) }\end{array}$ & $\begin{array}{l}\text { Menampilkan } \\
\text { Login Sukses dan } \\
\text { menampilkan } \\
\text { Form Menu Utama }\end{array}$ & $\begin{array}{l}\text { Sesua } \\
\text { i / OK }\end{array}$ \\
\hline 2. & $\begin{array}{l}\text { Klik menu } \\
\text { profil saya }\end{array}$ & $\begin{array}{l}\text { Menampilkan isi } \\
\text { profil }\end{array}$ & $\begin{array}{l}\text { Sesua } \\
\text { i / OK }\end{array}$ \\
\hline 3. & $\begin{array}{l}\text { Klik menu } \\
\text { info } \\
\text { lowongan } \\
\text { pekerjaan }\end{array}$ & $\begin{array}{l}\text { Menampilkan } \\
\text { informasi } \\
\text { lowongan kerja }\end{array}$ & $\begin{array}{l}\text { Sesua } \\
\text { i / OK }\end{array}$ \\
\hline
\end{tabular}

\begin{tabular}{llll}
\hline 4. & $\begin{array}{l}\text { Klik menu } \\
\text { rekomendasi } \\
\text { lowongan } \\
\text { pekerjaan }\end{array}$ & $\begin{array}{l}\text { Menampilkan } \\
\text { pekerjaan yang di } \\
\text { rekomendasikan }\end{array}$ & $\begin{array}{l}\text { Sesua } \\
\text { i / OK }\end{array}$ \\
5. & $\begin{array}{l}\text { Klik menu } \\
\text { logout }\end{array}$ & $\begin{array}{l}\text { Mengakhiri } \\
\text { program }\end{array}$ & $\begin{array}{l}\text { Sesua } \\
\text { i / OK }\end{array}$ \\
\hline
\end{tabular}

\section{KESIMPULAN}

Berdasarkan hasil perancangan dan pembuatan website bursa kerja di STMIK Yadika Bangil dapat diambil beberapa kesimpulan, diantaranya:

Dengan adanya program aplikasi website bursa kerja di STMIK Yadika Bangil dapat membantu alumni untuk mendapatkan informasi lowongan pekerjaan. Dengan menggunakan metode content based filtering dengan system rekomendasi membantu mahasiswa alumni untuk mendapatkan informasi lowongan pekerjaan yang sesuai dengan keahliannya.

$>$ Dalam aplikasi website ini terdapat dua login, yang pertama adalah login admin dan yang kedua login alumni. Pada login admin seorang administrator dapat mengupdate data lowongan sehingga user alumni dapat mendapatkan informasi lowongan pekerjaan yang up to date. Pada login alumni, user dapat mendapatkan informasi lowongan pekerjaan sesuai dengan keahliannya.

$>$ Pada penelitian ini telah berhasil membangun aplikasi bursa kerja berbasis website yang diimplementasikan dengan bahasa pemrograman PHP dan dari hasil implementasi dapat membantu pencari pekerjaan mendapatkan informasi lowongan pekerjaan

\section{REFERENSI}

[1] Adi, Puspaningtyas Sanjoyo, 2010, Sistem Rekomendasi Nilai Mata Kuliah Menggunakan Metode Content-Based Filtering, Seminar Nasional Informatika 2010, Universitas Sanata Dharma, Yogyakarta

[2] Andro, 2016, Decision Tree ID3 Untuk Rekomendasi Pemberian Beasiswa Di Sekolah ( Studi Kasus Di SMA 2 Rembang), Program Studi Pendidikan Teknik Informatika dan Komputer, Universitas Negeri Semarang

[3] Irfan, Moh, 2014, Sistem Rekomendasi: Buku Online Dengan Metode Collaborative Filtering, Jurnal Teknologi Technoscientia, Universitas Trunojoyo, Madura

[4] Nugraha, Feri Pebriansyah, Aplikasi Bursa Kerja Online Berbasis Website Dengan Sistem Rekomendasi Menggunakan Metode Content Based Filtering, Fakultas Ilmu Komputer Universitas Dian Nuswantoro, Bogor, Indonesia

[5] Putra, Aditya Fitri Hananta, dkk, 2014, Sistem Rekomendasi Mata Kuliah Pilihan Mahasiswa Dengan Content-Based Filtering Dan 
Collaborative Filtering (Studi Kasus: Universitas Brawijaya), Program Studi Informatika/Ilmu Komputer, Universitas Brawijaya, Malang

[6] Wahyu U, Bambang Tri, 2015, Sistem Rekomendasi Paket Wisata Se-Malang Raya Menggunakan Methode Hybrid Content Based Dan Collaborative, Jurnal Ilmiah Teknologi Dan Informasi ASIA, STMIK ASIA Malang
[7] Republik Indonesia. 1969. Undang-undang No. 14 Tahun 1969 tentang pokok-pokok ketenaga kerjaan

[8] Republik Indonesia. 1993. Perjanjian Kerja sama antar Departemen Pendidikan dan Kebudayaan dan Departemen Tenaga Kerja Republik Indonesia. No: 076 / U / 1993. No: Kep. 216 / Mei / 1993. Tentang Pembentukan Bursa Kerja dan Pemanduan Penyelengga Bursa Kerja di Satuan Pendidikan Menengah dan Pendidikan Tinggi 
Halaman Sengaja Dikosongkan 